P-ISSN : 2715-744X

\title{
Performativitas Identitas Gender dan Seksualitas dalam Novel Imarah Yakubian Karya Ala Al-Aswani
}

\author{
Herpin Nopiandi Khurosan \\ IAIN Salatiga
}

DOI:

\begin{tabular}{|l|l|}
\hline Article Info & \multicolumn{1}{c|}{ ABSTRACT } \\
Article history: & $\begin{array}{l}\text { This study examines aspects of the performativity of gender identity } \\
\text { and sexuality in the novel Imarah Yakubian by Alaa al-Awani. Through } \\
\text { Judith Butler's theory of performativity, the author examines how the } \\
\text { identity and gender sexuality performativity of the characters and how } \\
\text { the attitude of the characters in the novel Imarah Yaqubian in } \\
\text { responding to the dominance of heteronormativity. } \\
\text { The results showed that Egyptian society which was dominated by } \\
\text { heteronormativity ideology gave birth to the marginalization of } \\
\text { homosexuals. Individuals who have 'deviant' gender and sexuality } \\
\text { tendencies respond to compliance, negotiation, or resistance. } \\
\text { Compliance in the novel IY was shown by Abduh by positioning and } \\
\text { publicly showing himself as what was considered normal by the } \\
\text { general public. The moderate-negotiate response was demonstrated } \\
\text { by Hatim al-Rashid's figure by showing the things that were acceptable } \\
\text { to the public in the public sphere and showing what he wanted in the } \\
\text { private sphere. } \\
\text { Keywords: Performativity, Ala Al-Aswani, Judith Butler }\end{array}$ \\
& \\
& \\
&
\end{tabular}


P-ISSN : 2715-744X

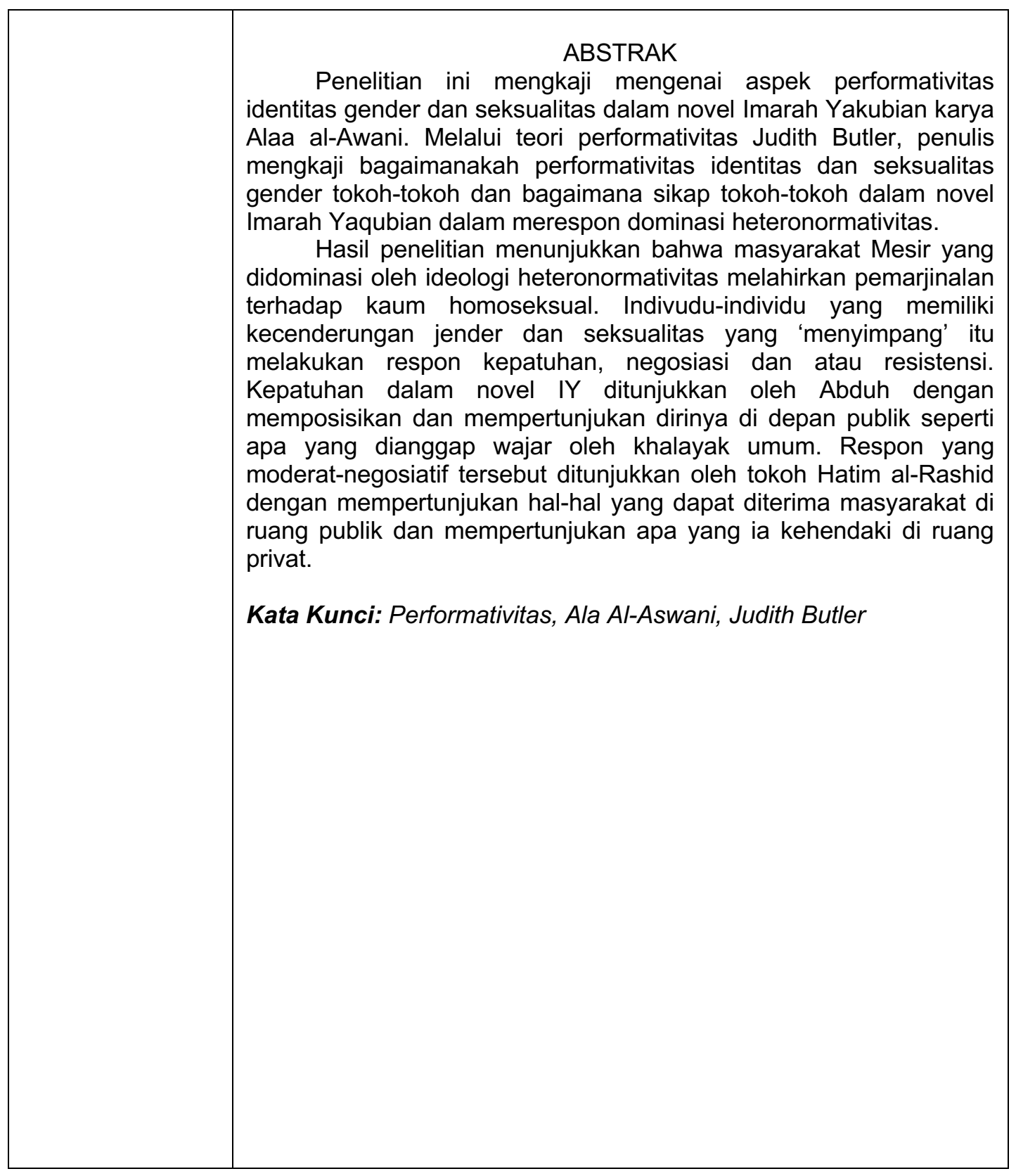

\section{PENDAHULUAN}

Kuatnya dominasi heteronormativitas dan adanya pemarjinalan oleh masyarakat umum yang didominasi oleh ideologi heteronormativitas, mendorong indivuduindividu yang memiliki kecenderungan jender dan seksualitas yang 'menyimpang' untuk melakukan respon terhadap ideologi dominan tersebut. Respon tersebut bisa berupa kepatuhan, negosiasi maupun resistensi yang strict. Respon tersebut 
tercermin dalam performativitas kaum homoseksual dalam kehidupannya.

Kondisi di mana heteronormativitas merupakan ideologi dominan serta dilanggengkan melalui keluarga, lingkungan, agama, dan negara juga terjadi di Mesir. Hal itu tercermin dalam novel Imarah Yakubiyan karya Alaa al-Aswani. Novel tersebut menceritakan mengenai kehidupan para penghuni Apartemen Yakubian di jantung Kota Kairo. Dalam novel tersebut terdapat tokoh Hatim al-Rashid yang yang merupakan seorang pimpinan redaksi sebuah koran berbahasa Perancis terkemuka di Kairo. Sejak kecil Hatim kecil hidup sendirian tanpa kasih sayang orang tua. Ia dibesarkan oleh pebantu keluarganya yaitu Idris al-Safarji yang berpengaruh pada kecenderungan gender sekaligus seksualitas Hatim.

Hingga pada usia matangnya setelah lama berpisah dengan Idris, ia bertemu dengan Abduh dan jatuh hati kepadanya. Abduh, mengingatkannya kepada cinta pertamanya yakni Idris yang berperformatifitas serupa.

Namun Hatim dan Abduh memiliki meski memiliki kecenderungan jender yang sama-sama dianggap menyimpang, mereka memiliki sikap yang berbeda terhadap heteronormatifitas.
Penelitian ini akan difokuskan pada performativitas identitas gender dan seksualitas dalam novel tersebut. Disinyalir dogma heteronormativitas menghambat tokoh-tokoh dengan orientasi seksual queer untuk melakukan coming out. Yang menarik di sini adalah bagaimana performativitas tokoh-tokoh tersebut dipertunjukkan di tengah lingkungan sosial yang didominasi oleh wacana heteronormativitas.

\section{IDENTIFIKASI MASALAH}

Adapun permasalahan yang penulis identifikasikan dalam penelitian ini adalah sebagai berikut:

1. Bagaimanakah performativitas identitas gender dan seksualitas gender tokoh-tokoh dalam novel Imarah Yaqubian karya Alaa alAswani?

2. Bagaimana sikap tokoh-tokoh dalam novel Imarah Yaqubian dalam merespon dominasi heteronormativitas?

\section{TUJUAN PENELITIAN}

Tujuan dari penelitian ini adalah mengungkapkan bagaimanakah performativitas identitas gender dan seksualitas gender tokoh-tokoh dalam novel Imarah Yaqubian karya Alaa al-Aswani serta 
mengungkapkan bagaimana sikap tokohtokoh dalam novel Imarah Yaqubian dalam merespon dominasi heteronormativitas.

\section{LANDASAN TEORI}

Tulisan ini melandaskan diri pada teori anti esensialisme khususnya mengeni teori identitas dan performativitas Judith Butler.

\section{Gender Trouble}

Gender dilihat sebagai sesuatu yang tidak stabil dan dapat berubah. Butler berpendapat bahwa gender adalah apa yang kamu lakukan dan bukan sebagaimana kita terlahir dan gender merupakan hasil dari konstruksi sosial dan tidak terlihat tetap seperti seks namun terlihat alami karena tidak mungkin dipisahkan dari politik dan interseks budaya yang berlangsung lama dan terproduksi bervariasi (1999:6).

Lalu Butler (1999: 25) mengkritik feminisme yang (1) mengeneralisasikan masalah dan karakteristik perempuan tanpa melihat permasalahan yang muncul dalam dunia perempuan itu sendiri, misalnya perempuan lesbian, perempuan mandul, transgender, dan lain sebagainya, (2) feminis menganggap bahwa gender adalah manifestasi dan akibat dari seks, sedangkan seks sendiri adalah esensi yang dikeluarkan, diaktualisasikan menjadi gender. Misalnya anggapan bahwa jiwa mempunyai penis maka seseorang disebut sebagai laki-laki dan seharusnya mencintai perempuan.

Sedangkan tidak mempunyai penis adalah perempuan (3) meyakini adanya stable point of reference. Istilah yang digunakan untuk menyebut seks adalah esensi dari gender dan hasrat, jika terlahir laki-laki maka harus bersikap maskulin dan menyukai perempuan, begitu sebaliknya. Oleh Butler, stable point of reference diartikan seks adalah bibit sedangkan gender dan desire adalah yang tumbuh darinya (Alimi, 2011: 4). Budaya masyarakat telah menciptakan identitas gender menjadi penyebab utama yang membuat identitas lain tidak dapat muncul - identitas dan praktik orientasi seksualnya tidak mengikuti seks ataupun gender.

Dari kritik Butler di atas dapat dilihat bahwa feminis gagal dalam hal menjawab antara relasi gender dan seksualitas. Feminis memahami perempuan hanya pada persoalan gender belaka. Sedangkan menurutnya perempuan juga harus dipahami pada seksualitasnya. Seks menurut Butler merupakan proses yang diatur oleh norma materialisasi seks. Jenis kelamin seks bukan materi yang bersifat tetap, tetapi terus menerus ditunjukkan untuk menciptakan subjek. 


\section{Identitas}

Pandangan esensial menganggap bahwa identitas sebagai sesuatu yang berasal dari dalam -intrinsik, bahwa autensitas, dan originalitas dalam identitas. Sehingga apa yang disebut maskulin, feminin, laki-laki, atau perempuan berasal dari dalam diri masing-masing orang. Identitas tersebut tidak akan erubah dan universal. Anti esensialis menolak asumsi demikian dengan menyatakan bahwa identitas bukanlah sebuah entitas tetap, namun merupakan sebuah diskursus deskriptif akan diri yang berubah sesuai dengan kondisi kultural dan sosial tertentu (Barker, 2011).

Butler (1999) bependapat bahwa identitas gender dapat dilihat sebagai suatu sejarah personal atau kultural atas makna yang diterima dan tunduk kepada suatu rangkaian praktik imitatif. Gender secara lateral mengacu pada imitasi lain dan secara sama-sama mengonstruksi ilusi suatu diri bergender yang primer dan interior atas mekanisme konstruksi itu. Identitas diri yang menjadi patokan Butler ( 2009: 133 ) adalah drag sebagai salah sebuah bentuk yang paling terlihat dari performativitas yang membentuk parodi dari norma-norma gender. Drag menyatakan keaslian menjadi salinan/ tiruan, dan tidak dapat dihindarkan. Idealnya tidak seorangpun yang dapat mewujudkan. Mengacu pada pendapat Butler maka identitas diri tidak dapat dipaksakan dalam tubuh tertentu. Seorang bertubuh laki-laki bisa menunjukkan perilaku pria maupun perilaku perempuan.

Judith Butler menekankan bahwa subyek selalu subject-in-process. Butler menilai pandangan feminis sebelumnya terfokus pada penyetaraan antara laki-laki dan perempuan, dimana hal ini mengasumsikan adanya suatu pre-existing subject. Asumsi ini menurunkan pandangan bahwa seorang perempuan harus mampu menyadari bahwa identitasnya merupakan konstruksi dari masyarakat, dan kesadaran ini membuat perempuan kembali pada subyek aslinya, setelah berhasil melepaskan diri dari konstruksi sosial dimana ia berada. Menurut Butler tidak demikian. Bagi Butler, subyek selalu dalam proses yang dibentuk oleh tindakan permormative. Subyek dalam pikiran Butler adalah sebagai actor yang memainkan perannya (perform their identity) di atas panggung. Sedangkan identitas itu sendiri merupakan suatu rangkaian proses yang tidak akan pernah berakhir. Bagi Butler, suatu identitas tidak memiliki asal, dan tidak 
juga memiliki akhir. Identitas subyek dilihat dari setiap tindakan performatifnya, namun tidak dapat dikatakan bahwa tindakan ini mengikuti pendahulunya, atau selalu ada pelaku di setiap tindakan, tidak seperti itu. Melainkan, menurut Butler, tindakan ini membentuk pelaku. Karena suatu identitas tidak memiliki awal ataupun akhir, maka bagi Butler suatu gender tidak dapat didasarkan pada entitas biologis seseorang. Satu-satunya dasar bagi identitas, gender, dan seksualitas adalah tindakan. Karena tindakan selalu berubah, maka identitas selalu berubah. Subyek tidak pernah menjadi identitas yang final, melainkan selalu in-process.

\section{Performativitas}

Konsep performativitas berangkat dari penjelasan Foucault (Mourad 2017). Terutama tentang ethics dan teknologi diri (technology of the self) yang dijelaskan dalam The Use of Pleasure (1990) dan The Care of The Self (1986). Ia menjelaskan hubungan ethics dengan self production, yaitu mengenai bagaimana diri subyek diproduksi oleh serangkaian praktik ethics. Maksudnya adalah bagaimana diri bertindak terhadap serangkaian ethics -standar yang menjadikan diri sosok tertentu, guna digambarkan kepada khalayak. Ini seperti halnya bagaimana diri bertindak menghadapi serangkaian penanda atas identitas diri (Alimi, 2011: 15).

Performativitas diartikan sebagai konstitusif yang berulangkali diwacanakan (Howland 2009). Performativitas bukanlah sebuah aksi tunggal, namun pengulangan dan sebuah ritual yang mencapai hasil melalui naturalisasi dalam konteks sebuah tubuh, dapat dimengerti bahwa hal ini terjadi berdasarkan durasi (Butler, 1999:XX). Dalam bab ketiga bukunya Gender Trouble Butler mengemukakan teorinya yang kontroversial bahwa penampilan gender adalah hal yang natural (Olson, 2001: 135).Penampilan gender dapat dilihat dari kata-kata atau juga dari sikap yang ditujukan pada kita juga sikap yang kita lakukan, misalkan : "Dia adalah perempuan." Kalimat itu lebih mengacu pada tubuhnya adalah tubuh perempuan, bukannya identitasnya sebagai perempuan. Sedangkan sikap yang kita lakukan, seperti mengikuti kontes kecantikan. Contoh, kontes kecantikan waria memperlihatkan pada kita bahwa tidak ada gender yang murni, karena para waria bersikap, berpakaian dan berdandan secara feminin sampai para juri ataupun penonton tidak dapat membedakan mereka dengan perempuan yang asli, sedangkan pada dasarnya mereka terlahir dengan jenis kelamin laki-laki. Maka Butler beranggapan gender adalah imitasi, bahwa tidak ada 
realitas yang benar-benar tetap seperti yang kita kira, semuanya tidak stabil dan dapat berubah. sama lain atau dengan kata lain, heteroseksual merupakan produk dari homoseksual. Dengan demikian, tidak ada yang esensi, yang ada hanyalah relasi.

\section{METODE PENELITIAN}

Untuk pengumpulan data penulis khusus yang diberikan untuk menunjukkan kecederungan dalam sistem gender Barat yang memandang heteroseksual sebagai normal dan semua perilaku seksual yang berbeda disebut sebagai perilaku menyimpang (Spargo, 2000: 73)

Para ahli studi queer menggabungkan antara teori sejarah seksualitas Foucault dengan teori dekonstruksi Derrida untuk mengkritik kecenderungan tersebut. Seperti Diana Fuss (Spargo, 2000: 45), ahli queer lainnya, yang mengaplikasikan gagasan Derrida tentang "supplement" (tambahan) untuk menganalisis oposisi heteroseksual/ homoseksual. Dalam hal ini, yang menjadi supplement adalah homoseksualitas, karena ia ditampakkan sekedar sebagai tambahan bagi heteroseksual, padahal, keberadaan heteroseksual tergantung pada keberadaan homoseksual. Sebagaimana bentuk-bentuk oposisi-oposisi lainnya seperti kuat/ lemah, aktif/pasif, rasional/emosional, begitu pula oposisi heteroseksual/homoseksual, pasangan oposisional tersebut saling bergantung satu menggunakan metode "simak", yaitu dengan menyimak satuan-satuan linguistik yang signifikan yang ada di dalam karya sastra yang menjadi sumbernya atas dasar konsepkonsep teoritik yang digunakan. Selanjutnya penulis menggunakan metode deskriptif analisis untuk menganalisis data-data yang telah disimak. Metode deskriptif analisis ini dilaksanakan dengan cara mendeskripsikan fakta-fakta yang ada dalam karya sastra, dalam hal ini heteronormativitas dalam novel Imarah Yakubian dan performativitas identitas gender dan seksual dalam novel Imarah Yakubian karya Alaa al-Aswani yang kemudian dilanjutkan dengan anlisis terhadap fakta-fakta tersebut.

\section{ANALISIS} DOMINASI HETERONORMATIVITAS SEBAGAI LATAR SOSIAL DALAM NOVEL IMARAH YAKUBIAN 
Novel Imarah Yakubian -yang selanjutnya penulis acu sebagai $I Y-$ merupakan novel karya pertama karya Alaa al-Aswani yang menceritakan mengenai para tokoh penghuni Apartemen Yakubian yang dibangun di Kairo pada tahun 1934. Novel ini berlatarkan kota Kairo Mesir pada tahun 2000-an yang di mana bangunan tersebut masih dihuni.

Sebagaimana di daerah Mesir lainnya, masyarakat di daerah tersebut -apartemen yakubian- merupakan masyarakat yang didominasi oleh ideologi heteronormativitas. Ada beberapa faktor yang menyebabkan Masyarakat penghuni Apartemen Yakubian khususnya dan masyarakat Mesir pada umumnya mempercayai ideologi heteronormativitas tersebut. Salah satu diantaranya adanya penyebaran ideologi heteronormativitas tersebut yang berkesinambunga melalui intitusi keagamaan sehinga melahirkan kepercayaan terhadap suatu tafsiran tertentu terhadap ajaran agama Islam yang melarang hubungan sesama jenis. Nilai-nilai tersebut diproduksi dan diinternalisasikan oleh masyarakat tersebut sepanjang sejarah sehingga mengakar dalam. Sehingga orang yang melanggar nilai-nilai tersebut dianggap menyimpang dan tidak normal.
Anggapa masyarakat penghuni Apartemen yakubian tersebut dapat dilihat dalam kutipan berikut:

Mayoritas penghuni apartemen yakubian mengetahui yang sebenarnya, tetapi mereka bisa menerima dan menghormatinya. Etika mereka terhadap setiap orang yang abnormal adalah didasarkan kepada kasih sayang mereka terhadapnya (alAswani, 2002: 225).

Dari kutipan di atas terlihat jelas bagaimana masyarakt penghuni apartemen yakubian menganggap bahwa orang yang memiliki kecenderungan gender dan seksualitas tertentu -dalam kasus ini Abduh yang berseksualitas homoseksual- dianggap sebagai orang yang abnormal dan meyimpang dari norma yang diyakini galibnya masyarakat Mesir yang penganut agama Islam. Ia dianggap sebagai manusia yang patut dikasihani. Meski ia dikasihani, tetap saja perilaku tersebut mencerminkan bagaimana orang berseksualitas tertentu tidak diterima dalam masyarakat.

Bahkan ada beberapa anggota masyarakat di apartemen yakubian yang alihalih menyayangi dan mengasihani Abduh, mereka justru malah menjauhi abduh akibat homoseksualitasnya tersebut.

... bahkan mereka melarang anakanaknya untuk bergaul dengannya (alAswani, 2002: 225). 
Anggapan masyarakat umum terhadap perilaku Abduh sebagai perilaku menyimpang menegaskan bagaimana kuatnya sistem kepercayaan dan norma yang dipegang oleh masyarakat umum. Kuatnya sistem yang diyakini tersebut pada akhirnya mengakibatkan para homoseksual diidealkan oleh masyarkat agar sesuai dengan norma yang berlaku, bertingkah-laku sebagaimana umumnya masyarakat bertingkah-laku.

... sebagaimana kepada Abduh, mereka memaafkannya, berinteraksi dengannya, dan menilainya sebagai orang yang harus dikasihani karena sedang berada dalam jalan yang tak sebagimana lazimnya. Mereka selalu mengulang-ulang bahwa segala sesuatu pada akhirnya adalah takdir dan nasib serta turunnya hidayah bagi orang seperti Hatim tidaklah jauh.

Sikap ketidaksetujuan masyarakat penghuni apartemen yakubian juga terlihat dalam kutipan ketika Hatim terus-menerus mencari keberadaan Abduh dengan menayakan alamat baru Abduh ke para penghuni apartemen yakubian tatkala Abduh pergi menjauhi Hatim (al-Aswani, 2002: 225).

Hatim menaiki tangga untuk kembali. Ia bertanya kepada para tetangga Abduh tentang alamatnya yang baru. Sepintas pandangan para penghuni atas atap terlihat tak peduli dan jawaban yang keluar terbaca agak sinis (bahasa tubuh mereka mengisyaratkan agar ia meninggalkan Abduh dan cukuplah apa yang sudah terjadi) (al-Aswani, 2002: 312).
Sebagai anggota masyarakat yang mengimani agama Islam, pada diri Abduh juga tertanam ideologi heteronormativitas yang sering kali ia renungkan. Ideologi tersebut kerap kali menekan Abduh sehingga ia merasa bersalah pada Tuhan akibat kecenderungan seksualitasnya dan perilaku seksnya. Hal itu terlihat dalam kutipan berikut:

Abduh hanya berdiam diri.

"Ada apa, sayangku?"

"Aku takut," ujar Abduh dengan suara pelan dan perasaan yang dalam.

"Takut pada siapa?"

"Tuhan yang Mahasuci."

"Kamu ini bicara apa, sayang?"

"Tuhan yang Mahasuci. Aku takut Ia akan melaknat kita atas apa yang selama ini kita lakukan."(al-Aswani, 2002: 198).

Perasaan bersalah Abduh tersebut merupakan cerminan kepercayaan ia terhadap ideologi heteronormativitas yang ia peroleh dan diinternalisasikan. Ideologi tersebut disebarkan terus-menerus melalui institusi agama hingga mencapai bentuknya yang melembangga.

"Tuhan melarang cinta seperti ini. Cinta seperti ini dosa besar. Besar sekali. Di desa, kami memiliki imam mesjid, namanya Syekh Darawi. Tuhan menyayanginya.... sewaktu khotbah Jumat, ia mengatakan 'Janganlah kamu melakukan hubungan seks sejenis, karena itu dosa besar. Arasy menjadi goncang karena murka Tuhan." (alAswani, 2002: 199). 
Institusi keluarga juga berperan besar dalam pembentukan, penyebaran dan internalisasi ideologi dominan heteronormativitas. Sejak kecil individuindividu ditanami ideologi dominan tersebut, bahwa apa yang gender yang baik adalah gender yang sesuai dengan seks yang di bawa sejak lahir. Artinya bahwa manusia yang terlahir dengan jenis kelamin laki-laki maka mesti bergender maskulin, dan yang terlahir wanita mesti bergender feminin. Begitu juga dalam aspek seksualitas, laki-laki dinaggap normal jika menyukai perempuan dan sebaliknya. Maka orang yang berorientasi seksualitas sesama jenis akan dianggap tidak normal sehingga patut dijauhi. Dan pandangan tersebut ditanamkan sejak kecil.

... bahkan mereka melarang anakanaknya untuk bergaul dengannya (alAswani, 2002: 225).

Selain dilanggengkan oleh regim of truth agama Islam, dan keluarga, ideologi heteronormativitas di masyarakat Mesir penghuni novel Imarah Yakubian juga dilanggengkan oleh regim of truth yang lain yakni negara. Negara di sini berperan sebagai pemegang komando kekuasaan yang menertibkan masyarakat melalui kepemimpinan moral maupun melalui kepemimpinan yang besifat subversif. Negara memiliki kekuasaan menentukan mana yang baik dan yang buruk, mana yang jelek dan indah, mana yang benar dan yang salah, dan mana yang wajar dan tak wajar. Melalui kekuasaan dan kepemimpinan moral Negara Mesir menanamkan ideologi normativitas melalui fungsionaris-fungsionaris hegemoniknya dan berbagai situs hegemoniknya. Negara Mesir dengan undang-undang negaranya melarang hubungan sesama jenis. Pemerintah Melarang hubungan sesama jenis tersebut nampak terang-terangan di muka publik. Pelarangan tersebut terlihat dari kutipan di mana pemerintah melalui aparatus negara subversifnya melakukan tindakan subversif terhadap cafe-cafe dan bar-bar yang menjadi tempat berkumpulnya para kaum homoseksual bercengkrama.

...jika ada mabahits (intel polisi) yang mengetahui aktivitas homoseksual berlebihan, tentu saja mereka akan membuat perhitungan lebih jauh... Aziz harus mengeluarkan uang suap... aktivitas homoseksual di negara seperti Mesir amat terlarang (al-Aswani, 2002: 56).

VII. ANALISIS PERFORMATIVITAS IDENTITAS GENDER DAN SEKSUALITAS DALAM NOVEL IMARAH YAKUBIAN KARYA ALA ALASWANI 
Performance dan performativity dalam novel Imarah Yakubian akan penulis jelskan pada bagian ini. Dalam novel $I Y$ dapat dilihat bagaimana berbagai bentuk gender ditampilkan dalam konteks sosial. Sebisa mungkin tubuh disesuaikan dengan norma di dalam masyarakat yang berlaku. Dalam konteks novel IY ini masyarakat yang di maksud adalah masyarakat penghuni Apartemen Yakubian yang berada di daerah Wasath al-Balad Ibu kota Mesir Kairo.

Sebagaimana dijelaskan pada poin Dominasi Heteronormativitas Sebagai Latar Sosial dalam Novel Imarah Yakubian di atas, masyarakat penghuni apartemen yakubian merupakan masyarakat yang disominasi oleh ideologi heteronormativitas. Oleh karena itu Tubuh dalam novel $I Y$ ini dipoles sesuai dengan selera masyarakat dan sesuai dengan stereotipe sosial mengenai apa yang pantas dan tidak pantas, apa yang cantik dan tidak cantik . Sebagaimana yang dikatakan Butler bahwa identitas gender sebenarnya merupakan pengulangan-pengulangan yang dipaksakan kepada individu tanpa mereka sadari sepenuhnya. Gender merupakan serangkaian tampilan tanpa esensi atau merupakan konstruksi masyarakat tentang maskulin-feminin yang dipaksakan kepada setiap individu. Bisa dibilang bahwa performance adalah kesesuaian seks dengan setereotipe gender. Artinya jika seseorang berkelamin laki laki dan berperilaku maskulin, maka hal merupakan performance. Sedangkan seseorang yang berkelamin lakilaki berpenampilan feminim maka hal itu disebut performativiti.

Dalam tulisan ini penulis akan melihat bagaimana performance dan performativitas tokoh-tokoh dalam novel $I Y$ ini direpresentasikan oleh Alaa al-Aswani. Tokoh yang dimaksud yakni Hatim al-Rashid dan Abduh. Ketiga tokoh tersebut memiliki performance dan perforativitas yang berebeda satu sama lain. Perbedaan tersebut dipengaruhi oleh tuntutan lingkungan dan respon para tokoh terhadap lingkungan yang didominasi oleh heteronormativitas tadi. Performativitas para tokoh di salam novel $I Y$ ini bisa dimaknai sebagai pemposisian diri mereka di tengam masyarakatnya.

\section{a. Performativitas Hatim: Negosiasi Terhadap Heteronormativitas.}

Tokoh pertama dan merupakan tokoh utama perihal performativitas dalam novel ini adalah Hatim al-Rashid. Ia merupakan seorang bangsawan tulen. Ibunya seorang wanita kulit putih berkebangsaan Perancis. Ayahnya, Dr. Hassan Rashid, seorang ahli hukum terkemuka di Mesir pada zamannya 
sekaligus dekan fakultas hukum di King Faruq University (sekarang bernama Cairo University) pada dasawarsa lima puluhan. Dr. Rashid merupakan salah satu dari seratus pakar hukum internasional terkemuka yang menjadi anggota asosiasi tersebut. Popularitas dan posisinya yang penting di berbagai institusi dan organisasi membuat ia semakin tenggelam dalam kesibukan sehingga menjauhkan ia dengan anaknya sendiri Hatim.

Begitupun halnya dengan Ibu Hatim yakni, ia sibuk bekerja sebagai penerjemah di kantor kedutaan besar Perancis di Mesir. Kesibukan kedua orang tuanya mengakibatkan Hatim kecil hidup kesepian. Ia hanya ditemani oleh pembantu keluarganya, Idris al-Safarji. Ia tidak tumbuh sebagaimana ank-anak kecil sebayanya. Ia kerap hidup terasing sehingga lebih menyayangi Idris yang selalu menemaninya ketimbang ayah dan ibunya.

Pada momen seperti itu performativitas identitas gender dan seksualitasnya mulai terbentuk. Idris al-Safarji pembantu yang selalu menemaninya merupakan seseorang yang berorientasi seksual sesama jenis. Idris kerap kali memperlakukan Hatim sebagai kekasihnya. Ia mencim wajah dan lehernya dan lain sebagainya. Perilakuan Idris yang memposisikan Hatim sebagai kekasihnya perlahan-lahan menuntun Hatim berkepribadian feminin. Hatim tumbuh menjadi lelaki yang lembut.

Ketika hatim berusia sembilan tahun, ketika Idris mencium wajahnya yang putih, Hatimpun balaas mencium bibir Idris. Keduanya lalu berciuman lama sekali. Idris lalu meyuruh hatim mencopot bajunya yang kemudian dipatuhi oleh Hatim.

... Idris mulai menciumi Hatim, ia merasakan kenikmatan. Saat itulah Idris mendesah dan mengeluarkan ungkapan-ungkapan dengan bahasa Nubia yang tidak dimengerti Hatim... Ia memperlakukan Hatim dengan lembut. Idris meminta Hatim memberitahunya jika ia merasa sakit sewaktu Idris memasukkan penisnya ke dalam anus Hatim (al-Aswani, 2002: 116).

Hubungan anatara hatim dan Idris berlanjut selama bertahun-tahun hingga ayah Harim meninggal karena serangan jantung. Setelah itu sang ibu mengurangi jumlah pembantu -termasuk Idris- untuk menghemat pengeluaran. Setelah itu tidak ada kabar lagi mengenai Idris. Sejak saat itulah orientasi gender dan seksualitas Hatim terbentuk menjadi lelaki yang bergender feminin dan memiliki orientasi homoseksualitas.

Dalam menjalani kehidupannya Hatim tidak bisa menunjukkan dirinya kehalak umum sebagai homoseksual. Hal itu dikarena 
kehidupan yang didominasi oleh heteronormativitas dirasakan tidak ramah terhadap orang semacam Hatim. Di Mesir sudah menjadi kesepakatan umum bahwa orang yang homoseksual tidak layak untuk memimpin sebuah organisasi, perusahaan, ataupun institusi lainnya. hal itu bisa dilihat dari kutipan berikut.

Seseorang dengan kelainan seks secara psikologis tidak layak memimpin suatu pekerjaan di lembaga apapun karena yang bersangkutan mengidap kompleksitas psikologis yang disebabkan kelainan seks (al-Aswani, 2002: 257).

Ilmu psikologi sebagai rejim kebenaran mengontruksi bahwa seseorang yang memiliki kecenderungan seksualitas tidak cocok untuk memimpin suatu organisasi tertentu. Hal ini menunjukan bahwa kaum heteroseksual melalui psikologi melegitimasi seuatu wacan agar dianggap sebagai kebenaran. Hal itu menunjukkan bagaimana pengetahuan itu merupakan sebuah kekuatan yang mampu mengkonstruksi masyarakat agar mempercayai suatu wacana dan meminggirkan orang dengan kritreria tertentu.

Ketidakadilan dan peminggiran kaum homoseksualitas dalam kasus ini Hatim tidak berhenti sampai di situ saja. Pada bagian lain novel ini diceritakan bagaimana Hatim yang memiliki kapabilitas mumpuni untuk mengikuti suatu partai politik tertentu disingkirkan. Hak-hak ia sebagai manusia dicabut begitu saja oleh karena ia seorang homoseksual. Sebagai homoseksual Hatim mendapatkan perlakuan yang berbeda. Sikap tersebut disebut nonviolence oleh Butler. Sikap tersebut adalah kekerasan meski tidak menampakkan kekerasan fisik. Tindakan tersebut nampak adil namun keberadaanya membutuhkan komitmen keberlangsungan. Hal itu bisa disebut dengan fasisme militan yang sifatnya agresif meski tanpa kekerasan fisik (Butler 2020).

Pengetahuannya yang mendalam tentang sosialisme pernah membuatnya hampir masuk sebagai bagian dari jaringan sosialisme rahasia Partai Buruh dan Sosialis Mesir. Akan tetapi, gosip akan kelainan seks Hatim membuat beberapa petinggi parta itu tak menerimanya (al-Aswani, 2002: 258)

Mengingat peristiwa penolakan tersebut, Hatim yang kemudian diceritakan menjabat sebagai ketua redaktur koran berusaha menutupi kecenderungan feminin dan homoseksualitasnya di muka umum. Kehidupan rahasia Hatim sebagai homoseksual berada dalam kotak terkunci yang dipenuhi permainan terlarang dan dosa yang ia buka tiap malam untuk dinikmatinya 
lalu menutupnya kembali dan berusaha melupakannya ketika pagi datang.

Hatim berusaha membatasi penyimpangan-penyimpangan

hidupnya sampai pada batas sesempitsempitnya... ia hidup sehari-hari sebagai pemimpin redaksi koran terkemuka.. dan setiap malam ia bersenang-senang di ranjang... (alAswani, 2002: 259).

Untuk tampil di muka umum dan diperlakukan layaknya manusia pada umumnya Hatim harus berpenampilan layaknya laki-laki yang maskulin dan mengubur dalam-dalam agar kecenderungan homoseksualnya tidak terlihat oleh masyarakat. Ketika masuk kantor hatim harus memperhatikan penampilannya agar terlihat maskulin. Mau tak mau hatim harus menunjukkan diri di hadapan bawahannya setegas mungkin.

Penampilannya tampak necis, gagah dan menawan. Wajahnya tampan, putih, dan bersih... Aura campuran genetis antara lelaki Mesir dan Wanita Perancis tampak memancar dari wajahnya (al-Aswani, 2002: 245).

Hatim nampak serius, kuat, lebih dari pemimpin biasa. Ia menghabiskan seluruh waktunya dengan bawahannya tanpa sedikitpun gerak-gerik yang mengungkapkan kedenderungan penyimpangan itu (al-Aswani, 2002: 256).

Dua kutipan di atas emnunjukan bagai mana hatim mempertunjukkan dirinya di hadapan umum, khususnya di tempat kerjanya. Hatim dengan hati berat Harus menekan hasratnya untuk menyatakan diri dan untuk hidup dengan caranya sendiri. Pada kutipan pertama peenampilan fisiknya ia pertunjkkan agar terlihat setampan mungkin, sejantan mungkin, segagah dan semenawan mungkin di hadapan bawahannya.

Sedangkan pada kutipan yang kedua, hatim melalui gestur tubuhnya berusaha dengan sungguh-sungguh untuk menampilkan tampang yang serius, kuat. Kedua hal itu baik pertunjukan yang bersifat fisik maupun gestur ia pertunjukan secara berulang-ulang demi menutupi kenyataan sesungguhnya bahwa ia penyuka sesama jenis dan menutupi hasratnya untuk tampil feminin.

Performa yang ia tampilkan di kantor tempat ia bekerja berbeda seratus delapan puluh derajat dengan apa yang ia tampilkan di ruang privat. Ketika ia di rumah, ia bebas mengekspresikan gendernya. Ia bebas berperilaku dan menunjukkan dirinya. Hal itu terlihat dari pakainan yang ia kenakan. Hatim pandai memilih busana rumah yang dikenakannya. Ketika malam, misalnya, Hatim kerap mengenakan pakaian tidur berwarna merah pucat, menyesuaikan denga warna anggur yang kerpa diteguknya. Pada piyamanya selalu terdapat bordiran dengan 
motif bunga, juga helai-helai sutra yang menghiasinya. Di lehernya tergantung seuntai kalung emas berbusana feminin. Bahkan ia merupakan orang yang senantiasa merawat tubuhnya, memperhatikan berat badan dan sangat detai dalam urusan kecantikan.

Ia pun memulai meluluri bagian tertentu dari wajahnya dengan krim, mencukur janggut dan kumisnya, juga bulu cambangnya (al-Aswani, 2002: 119).

Adapun ketika ia pergi ketempattempat pertemuan rahasia para gay, maupun pesta-pesta homoseksual di bar-bar tertentu di kota Kairo, ia mempertunjukan penampilan fisik yang berbeda ketika ia pergi ke kantor koran yang ia pimpin ataupun ketika ia berada di rumah. Hatim berpenampilan dengan dandanan yang wajar namun dengan menampilkan hal-hal tertentu yang bisa menunjukkan bahwa ia adalah seorang homoseksual.

Ada bahasa tertentu yang digunakan oleh kaum homoseksual di Mesir. Mereka berkomunikasi dengan bahasa dan isyarat tubuh yang tak dipahami oleh orang lain. Seperti ketika berjabat tangan untuk berkenalan mereka menggerakan jemari dengan gerakan tertentu dan mengaitkan kelingking kepada yang lain yang menunjukkan identitas seksualitasnya. Contoh lainnya semisal ketika seseorang menaruh jemarinya di atas dada yang lain itu adalah isyarat kehendak memiliki dengan sepenuh hati.

Perbedaan penampilan hatim di momen dan tempat tertentu sebagaimana dijelaskan di atas merupakan bentuk performativitas Hatim dalam mengarungi kehidupan sebagai seorang homoseksual. Hatim merupakan contoh seseorang yang memiliki 'kelainan' gender dan seksualitas yang berusaha menegosiasikan apa yang ia kehendaki dengan lingkungan tempat ia berada. Hatim merupakan orang yang 'cinta damai' ia tahu posisi dan tahu kapan dan bagaimana menempatkan diri. Tindakan Hatim berada dalam posisi in-between antara menolak dan menerima dominasi heteronormativitas. Di sisi lain ia tak mau dikucilkan dan diperlakukan tak adil, tapi di sisi lain ia ingin mengaktualisasikan dirinya sebagai seorang homoseksual.

\section{b. Performance Abduh: Patuh Terhadap Heteronormativitas}

Tokoh Abduh dimunculkan oleh Alaa al-Aswani dalam novel $I Y$ ketika ia diajak oleh Hatim ke bar Chez Nouz yang berada di bilangan pusat kota Kairo. DI bar tersebut Abduh dikenalkan kepada teman-teman Hatim yang juga merupakan para homoseks. Bar Chez Nouz tersebut merupakan bar yang 
dikenal oleh oleh orang-orang tertentu sebagai tempat pertemuan, kencan, memadu kasih dan pesta homoseks.

Ia datang bersama seorang lelaki muda berperawakan tegap, berkulit coklat, dengan rambut yang dipotong cepak. Sekilas lelaki muda tersebut mirip tentara (al-Aswani, 2002: 57).

Hatim dikenalkan kepada pembaca dengan tampilan yang maskulin. Konotasi maskulin tersebut dapat dilacak dengan melihat kata-kata yang dihadirkan al-Aswani pada kutipan di atas. Kata tegap selalu diidentikan sebagai ciri khas lelaki yang maskulin, kata itu mencitrakan suatu struktur tubuh yang kokoh dan kuat. Tegap itu dioposisikan dengan perawakan yang lembut dan lemah yang biasanya diasosiasikan dengan perempuan. Selain itu al-Aswani menggambarkan Abduh dengan kata berkulit coklat. Frase tersebut bisa berimplikasi banyak, namun jika dikaitkan dengan maskulinitas, Frase tersebut bisa mengimplikasikan makna 'kulit yang terbakar matahari'. Lelaki yang maskulin menurut kebudayaan Mesir adalah lelaki yang bekerja keras di lapangan. Pekerjaan yang diidentikkan dengan laki-laki sebagai jenis kelamin oleh budaya Mesir adalah pekerjaan seperti di perkilangan minyak, pertambangan, perkebunan, militer dan lain sebagainya. Lelaki tidak diidentikkan dengan pekerjaan-pekerjaan domestik di dalam rumah.

Kemaskulinan laki-laki juga dapat dilihat dari frase 'rambut yang dipotong cepak'. Frase tersebut mengimplikasikan sebuah penampilan fisik yang diasosiasikan dengan laki-laki. Sebagaiman lumrahnya di Mesir, lelaki cenderung berambut pendek. seseorang yang berambut panjang biasanya selalu berjenis kelamin perempuan.

Berbeda dengan perempuan, lelaki tidak dituntut oleh lingkungan esensialisme untuk memanjangkan rambutnya. Untuk lelaki tidak ada pameo 'rambut adalah mahkota laki-laki'. Sehingga di Mesir dengan melihat tampilan fisik rambut cepak, nyaris bisa dipastikan bahwa ia seorang laki-laki.

...Dada Abduh yang telanjang terlihat bidang dan berwarna gelap. Di sana tumbuh bulu-bulu yang lebat. Hatim menciumi dada abduh...

Dada yang bidang merupakan performance laki-laki yang dianggap ideal oleh masyarakat luas. Lelaki yang maskulin harus memiliki dada yang bidang. Atau setidaknya maskulinitas seorang laki-laki akan dipandang lebih rendah kadarnya jika ia tidak memiliki dada yang bidang. Dada Bidang hatim merupakan bentukan yang tidak muncul begitu saja. Ia merupakan hasil dari pengolahan dengan proses tertentu. 
Tubuh Abduh diusahakan untuk patuh. Tubuh diposisikan sebagai situs yang dikonstruksi untuk menyesuaikan dengan ideologi patriarki. Sadar ataupun tidak, Abduh mau tidak mau menuruti dan menerima bahwa untuk menjadi seorang lelaki maskulin ia harus mengenakan dan melakukan macammacam bentuk doktrin tentang bagaimana menjadi seorang lelaki tampan, memenuhi berbagai kriteria masyarakat tentang maskulin dan mempertunjukkan penampilan itu utuk mendapatkan modal sosial dalam pengertian Bourdieu.

Pengulangan-pengulangan tampilan gender yang dilakukan oleh Abduh ia mulai semenjak ia kecil hingga tanpa ia sadari terus ia internalisasikan segala macam bentuk doktrin bagaimana menjadi maskulin tersebut. Dalam pengulangan tampilan gender tersebut, ia tentunya juga dikondisikan oleh lingkungan serta orang-orang yang ada di dekatnya. Hal itu tampak dari kutipan berikut:

Hatim membelikan beberapa pakaian baru untuk kekasihnya, Abduh. Celana panjang yang mampu membentuk ototototnya yang kuat, baju dan kaus berwarna cerah sehingga menerangi wajahnya yang kecoklatan dan kerah terbuka yang selalu menampilkan tulang leher serta bulu dada yang tebal (al-Aswani, 2002: 119).
Di balik otot-otot yang kuat terdapat makna maskulinitas. Bahwa lelaki idealnya memiliki otot yang kuat. Otot-otot yang kuat tersebut sebajugagaimana tulang leher yang kuat memiliki nilai ketika ia dipertunjukkan. Kedua bagian tubuh itu mencitrakan diri yang kuat pula, citra diri yang dikonstruksi oleh masyarakat patriarki. Untuk mempertunjukkan tubuh yang patuh pada ideologi patriarki tersebut, si pemilik tubuh tersebut juga harus mempertunjukkan tubuh idealnya tersebut dengan pakaian-pakaian yang menunjung bagi pertunjukan tersebut. Dalam kutipan novel $I Y$ di atas terlihat Abduh diharuskan secara halus oleh ideologi patriarki menggunakan pakaian yang mempertontonkan kemaskulinannya melalui pakaian-pakainan yang di berikan hatim. Di sini terlihat bahwa Hatim juga terpengaruhi ideologi yang mengharuskan seorang lelaki itu berpenampilan demikian.

Identitas Abduh dibangun baik oleh dirinya maupun oleh orang-orang yang ada di sekitarnya. Identitas bukanlah sesuatu yang sifatnya esensial, iamerupakan serangkaian cara berpenampilan. Identitas Abduh mulai dikonstruksi atau megacu pada istilah Butler, dimaterialisasi, sadar tidak-sadar, langsung maupun tidak langsung oleh dirinya sendiri dan orang-orang yang ada di sekitarnya. Tidak semua pengulangan identitas gender itu 
merupakan pengulangan yang dalam prosesnya disadari sepenuhnya.

Spargo (2000: 58) berpendapat bahwa konsep performativitas bukanlah seperti proses memilih pakaian di dalam lemari dalam mana individu bebas memilih, tetapi sebaliknya, individu dipaksa atau tanpa sadar mengulangi tampilan-tampilan gender yang sudah tersedia. Dalam kasus Abduh di atas, ia hanya menerima begitu saja apa yang disituasikan oleh lingkungannya. Terlihat adanya pertemuan antara tampilan gender dengan kapitalisme, di mana yang kemudian ini memamfaatkan selera masyarakat tentang nilai-nilai maskulinitas.

\section{PERILAKU, PERAN, DAN} AKTIVITAS SEKSUAL

Berbicara mengenai perilaku dan peran dalam hubungan homoseksual berarti berbicara mengenai sesuatu yang ingin ditolak oleh hubungan homoseksual itu sendiri.

Dalam novel IY Alaa al-Aswani menceritakan bahwa di dalam pergaulan homoseksual Mesir, khususnya di kalangan kaum gay, terdapat penggolongan peran atau perilaku dalam hubungan homoseksual. Penggolongan tersebut terdiri dari Kodiana dan Burghal. Yang terdahulu adalah istilah yang mengacu pada seorang homoseksual yang memiliki karakteristik pasif-objek, adapun yang kemudian mengacu pada seorang homoseksual yang memiliki karakteristik aktif-subjek.

... di mata mereka Hatim merupakan seorang Kodiana -homoseks pasifobjek. Para Burghal -homoseks aktifsubjek- sangat menghargainya dan memperlakukannya dengan lembut karena Hatim adalah wartawan dan pemimpin redaksi koran Mesir terkemuka berbahasa Perancis, Le Caire (al-Aswani, 2002: 55).

Sebagaimana telah dijelaskan oleh penulis pada bagian awal, bahwa pada dasarnya Hatim memiliki identitas gender feminin dan seksualitas homoseksual. Hatim memiliki karakteristik yang lembut, sensitif, serta manja dan mudah menangis. Namun karakter itu tidak melulu menempel pada Hatim. Ada sebuah criss-crossing gender yang muncul dalam novel ini. Hatim yang sensitip ternyata memiliki sisi yang tegas dan kuat, begitupun sebaliknya dengan Abduh, dalam abduh yang kuat dan perkasa ada titik feminin dan rapuh. Abduh nangis terseduhseduh ketika anak semata wayangnya hasil buah pernikahannya dengan Hadya meninggal dunia. Pada saat itu batin Abduh tersedu-sedu, dan di sanalah kemaskulinan Hatim muncul. Hatim menghibur Abduh dan memberikan bahunya sebagai sandaran. 
Kondisi hubungan antara Hatim dan Abduh, Serta adanya criss-crossing dalam diri mereka masing-masing yang ia pertunjukkan merupakan performativitasperformativitas yang mempertegas nosi bahwa identitas adalah sesuatu yang dapat diubah, dapat di-mix-match-kan. Individu dapat menjadi sosok feminin dan maskulin sekaligus. Individu tidak dapat dibatasi hanya dengan role kodiana dan Burghal yang ajeg semata.

Identitas dapat diubah-ubah dan dipilah-pilah, sebagaimana jika seseorang memilih pakaian yang hendak mereka kenakan. Identitas bukanlah merupakan sesuatu yang given, namun ia merupakan imitasi, merupakan pengulanganpengulangan dan peniruan yang dimaterialisasikan. Identitas meski terkadang bersifat relatif stabil, ia pada hakikatnya merupakan hal yang temporal belaka.

Hal itu dapat dilihat dari perubahan orientasi seksual dari Abduh. Pada mulanya, Abduh merupakan seorang pribadi yang heteroseksual. Hal itu dapat dibuktikan dengan statusnya yang memiliki seorang istri dan seorang anak. Kondisi ekonomi Abduh yang miskin memaksa ia membanting tulang dan kerja serabutan. Ditambah ia selanjutnya terkena wajib militer sehingga mengakibatkan ia kesulitan untuk mencari uang guna menghidupi keluarganya. Singkat cerita ia bertemu dengan Hatim yang menghendaki hubungan seksual dengannya.

...Abduh berutang kepada beberapa tetangganya sebesar 3.000 pound... ia putus asa mencari pekerjaan... ia pernah menjadi tukang batu... (al-Aswani, 2002: 117)

Keduanya duduk berdampingan di dalam mobil dan suasana terasa hening... ia menjelaskan rencananya...Hatim membutuhkan Abduh, dan Abduh membutuhkan uang dan pekerjaan dari Hatim... (al-Aswani, 2002: 117)

...sekalipun begitu, hasrat yang mulanya perasaan risih dan bersalah sedikit demi sedikit luruh dan beranjak menjadi hasrat yang betul-betul lepas (al-Aswani, 2002:118)

Hal itu menunjukkan bahwa kecenderungan seksualpun tidaklah bersifat alamiah, namun merupakan pengulanganpengulangan yang bersifat imitasi, tidak stabil dan berubah-ubah.

\section{KESIMPULAN}

Mesir merupakan negara yang didominasi oleh ideologi heteronormativitas. Dominannya ideologi tersebut melahirkan pemarjinalan masyarakt umum yang terhadapa kaum homoseksual. Akibatnya indivudu-individu yang memiliki kecenderungan jender dan seksualitas yang 'menyimpang' itu melakukan respon 
terhadap ideologi dominan tersebut. Respon tersebut bisa berupa kepatuhan, negosiasi maupun resistensi yang strict terhadapnya yang tercermin dalam performativitas kaum homoseksual dalam kehidupannya.

Kepatuhan dalam novel $I Y$ ditunjukkan oleh Abduh. Sebagai homoseksual dan masyarakat termarjinalkan ia tunduk pada ideologi dominan heteronormativitas dengan memposisikan diri dan mempertunjukan dirinya di depan publik seperti apa yang dianggap wajar oleh khalayak umum. Selain patuh, respon kaum homoseksual juga bisa bersifat negosiasi dengan mempertunjukan hal-hal yang dapat diterima masyarakat di ruang publik dan mempertunjukan apa yang ia mau diruang privat. Respon yang moderatnegosiatif tersebut ditunukkan oleh tokoh Hatim al-Rashid.

\section{DAFTAR PUSTAKA}

Al-Aswani, Alaa. 2002. Imarah Yakubian. Kairo: Dar al-Shuruk.

Alimi, Moh. Yasir. 2011. Judith Butler: Gender/ Seks sebagai "Pertunjukan" dan Tawa Medusa. Makalah dalam Kuliah Umum Filsafat di Salihara Jakarta.

Barker, Chris. 2011. Cultural Studies: Teori dan Praktik. Yogyakarta: Kreasi Wacana.
Butler, Judith. 1999. Gender Trouble (Feminism and the Subversion of Identity). London: Routledge.

Butler, Judith. 2004. Performativity, Precarity, and Sexual Politic. Madrid: Antropologos Iberoamericanos.

Butler, Judith. 2020. The Force of NonViolence: An Ethico-Political Bind. London-New York: Verso.

Howland, Elizabeth E. E. 2009. "A Search for Authenticity: Understanding Zadie Smith's White Teeth Using Judith Butler'sPerformativity and Jane Austen's Satire.” East Carolina University.

Mourad, Ghada. 2017. "Unruly Bodies: Modernity, Dissensus, and the Political Subject in the Postcolonial Arab World." University of California, Irvine.

Olson, Tanya. 2001. "Beyond The Pale: Queer Theory and The Politics of Irish Literature". Disertasi. The University of North Carolina at Greensbroro.

Spargo, Tasmin. 2000. Michael Foucault and Queer Theory. New York: Totem Book. 